\title{
p27, The Cell Cycle and Alzheimer's Disease
}

\author{
Ana García-Osta ${ }^{1}$, Jinya Dong ${ }^{2}$, María Jesús Moreno-Aliaga ${ }^{3,4}$ (D) and Maria Javier Ramirez ${ }^{2, *}$ (D)
}

Citation: García-Osta, A.; Dong, J.; Moreno-Aliaga, M.J.; Ramirez, M.J. p27, The Cell Cycle and Alzheimer's Disease. Int. J. Mol. Sci. 2022, 23, 1211. https://doi.org/10.3390/ijms23031211

Academic Editor: Toshio Ohshima

Received: 7 December 2021

Accepted: 20 January 2022

Published: 21 January 2022

Publisher's Note: MDPI stays neutral with regard to jurisdictional claims in published maps and institutional affiliations.

Copyright: (C) 2022 by the authors. Licensee MDPI, Basel, Switzerland. This article is an open access article distributed under the terms and conditions of the Creative Commons Attribution (CC BY) license (https:// creativecommons.org/licenses/by/ $4.0 /)$.
1 Neurosciences Program, Center for Applied Medical Research (CIMA), University of Navarra and IdiSNA, 31008 Pamplona, Spain; agosta@unav.es

2 Department of Pharmacology and Toxicology, University of Navarra and IdiSNA, 31008 Pamplona, Spain; jdong@alumni.unav.es

3 Center for Nutrition Research and Department of Nutrition, Food Science and Physiology, University of Navarra and IdiSNA, 31008 Pamplona, Spain; mjmoreno@unav.es

4 CIBER Physiopathology of Obesity and Nutrition (CIBERobn), Carlos III Health Institute, 28029 Madrid, Spain

* Correspondence: mariaja@unav.es

\begin{abstract}
The cell cycle consists of successive events that lead to the generation of new cells. The cell cycle is regulated by different cyclins, cyclin-dependent kinases (CDKs) and their inhibitors, such as $\mathrm{p} 27^{\mathrm{Kip} 1}$. At the nuclear level, $\mathrm{p} 27^{\mathrm{Kip} 1}$ has the ability to control the evolution of different phases of the cell cycle and oppose cell cycle progression by binding to CDKs. In the cytoplasm, diverse functions have been described for $\mathrm{p} 27^{\mathrm{Kip} 1}$, including microtubule remodeling, axonal transport and phagocytosis. In Alzheimer's disease (AD), alterations to cycle events and a purported increase in neurogenesis have been described in the early disease process before significant pathological changes could be detected. However, most neurons cannot progress to complete their cell division and undergo apoptotic cell death. Increased levels of both the $\mathrm{p} 27^{\mathrm{Kip} 1}$ levels and phosphorylation status have been described in AD. Increased levels of $\mathrm{A} \beta 42$, tau hyperphosphorylation or even altered insulin signals could lead to alterations in $\mathrm{p} 27^{\mathrm{Kip} 1}$ post-transcriptional modifications, causing a disbalance between the levels and functions of $\mathrm{p} 27^{\mathrm{Kip} 1}$ in the cytoplasm and nucleus, thus inducing an aberrant cell cycle re-entry and alteration of extra cell cycle functions. Further studies are needed to completely understand the role of $\mathrm{p} 27^{\mathrm{Kip} 1}$ in $\mathrm{AD}$ and the therapeutic opportunities associated with the modulation of this target.
\end{abstract}

Keywords: cell cycle; Alzheimer's disease; p27 Kip1; neurogenesis; cytoplasm-nucleus shuttle

\section{Cell Cycle \\ 1.1. Cell Cycle and Cell Cycle Regulators}

The cell cycle is a complex and highly regulated process by which a cell divides into two cells. It is mainly constituted by four phases: Gap 1 (G1), DNA synthesis (S), Gap 2 (G2) and mitosis (M). The most important phases are $S$, when DNA replication occurs, and $\mathrm{M}$, when the cell divides into two daughter cells. G1 is the first gap, preceding $S$, when cells prepare for DNA replication. During the second gap, G2 (after S), the cell prepares for mitosis (Figure 1). Many cells from the adult body exit from the cell cycle and stay in a quiescent state (G0). Several cells, such as neurons and most differentiated cells, do not enter again into the cell cycle but others, such as lymphocytes, exit and re-enter the cell cycle repeatedly throughout their lifetime [1-3].

The transitions between the stages in the cell cycle are finely coordinated by a family of serine/threonine kinases known as cyclin-dependent kinases (CDKs), which are active only when they are associated with their specific cyclins [4-6]. In contrast to cyclins, cyclindependent kinase inhibitors (CDKIs) inhibit the activities of CDKs. Phosphorylation and dephosphorylation events also regulate CDK activity. The ubiquitin-mediated proteolysis of cyclins and CDKIs has also been reported to be involved in cell cycle regulation [7]. 


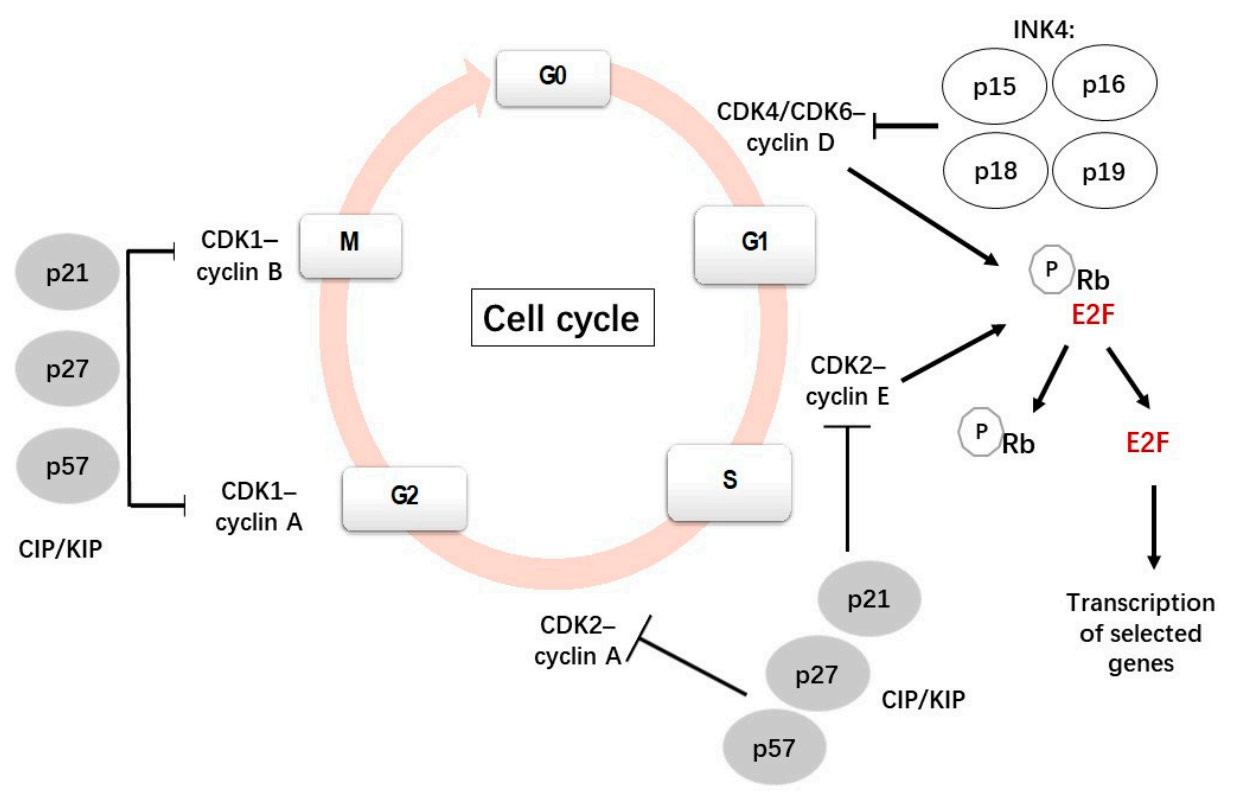

Figure 1. A scheme showing the canonical cell cycle and its main regulatory mechanisms $[8,9]$.

Each CDK is able to associate with different cyclins with a specific role in each phase. For instance, when a cell is withdrawn from the quiescent state and enters the G1 phase, Dtype cyclins (D1, D2, D3) bind and activate CDK4/6; these active complexes phosphorylate and inactive the retinoblastoma $(\mathrm{Rb})$ protein family, which plays a negative regulation of the cell cycle. The phosphorylation of the $\mathrm{Rb}$ protein leads to the release of transcription factor E2F1 from its transcriptionally repressive complex, allowing the transcription of genes and the synthesis of the proteins necessary for DNA replication [10]. During the late G1 phase, cyclin $\mathrm{E}$ associates with CDK2 to progress through the $\mathrm{S}$ phase, subsequently binding to cyclin A during the early $S$ phase and promoting DNA synthesis and replication [7,11].

Cyclin A also binds to CDK1; the CDK1/cyclin A complex is necessary for the transition from the $\mathrm{G} 2$ to the $\mathrm{M}$ phase. Cyclin $\mathrm{A}$ is degraded after prometaphase by a polyubiquitination-dependent mechanism [7]. CDK1 then associates with cyclin B to initiate the mitotic program by the phosphorylation of selected proteins. Subsequently, cyclin B is degraded by ubiquitin-mediated proteolysis, which is necessary to exit the M phase $[7,12]$.

The activity of the CDKs/cyclin complexes can be inhibited by CDKIs, which are classified into two families: INK4 (p15 ${ }^{\text {Ink4b }}, \mathrm{p} 16^{\text {Ink4a }}, \mathrm{p} 18^{\text {Ink4c }}$ and p19 ${ }^{\text {Ink4d }}$ ) and CIP $/$ KIP (p21 ${ }^{\text {Cip1 }}$, p27 ${ }^{\text {Kip1 }}$ and p57 ${ }^{\text {Kip2 }}$ ). Members of the INK family bind specifically to CDK4/6, preventing its interaction with cyclin $\mathrm{D}$ and regulating the quiescent state. By contrast, members of the CIP/KIP family have the ability to inhibit all cyclin/CDK complexes, including the CDK2/cyclin E, CDK2/cyclin A, CDK1/cyclin A and CDK1/cyclin B complexes $[13,14]$. p21 and p27 can bind and inhibit the cyclin E-CDK2 and cyclin A-CDK2 complexes and will stop the cell cycle at G1 [15]. In addition to the function of inhibiting cyclin-CDK activity, nuclear CIP/KIP proteins have alternative roles, such as regulators of nuclear import, apoptosis and cell motility, when they are located in the cytoplasm [16].

The deregulation of the cell cycle at any stage can result in a series of disorders, including cancer and neurodegenerative diseases among others [13]. In this context, it is relevant to mention cellular senescence, which is characterized by a stable cell cycle arrest, in which cells are unable to proliferate in response to mitogenic stimuli and optimal growth conditions [17]. Despite being in an arrested state, senescent cells are viable although they exhibit dramatic changes in gene expression and metabolic alterations as well as possessing a complex senescence-associated secretory phenotype [17]. In senescence cells, growth arrest occurs in the G1 and probably in the G2 cell cycle phases and seems to be mainly mediated by the $\mathrm{p} 53 / \mathrm{p} 21^{\mathrm{WAF} / \mathrm{CIP} 1}$ and $\mathrm{p} 16^{\mathrm{INK} 4} / \mathrm{pRb}$ pathways $[18,19]$. Growing 
evidence indicates that senescence cells contribute to aging and the development of agerelated disorders, including chronic inflammation, Alzheimer's disease and cardiovascular disorders [20-22].

\subsection{Cell Cycle and Neurogenesis}

Neurogenesis is the process of division of the neural stem cells (NSCs) and progenitor cells into daughter cells that migrate to corresponding brain areas and give rise to new neurons. It is linked to the cell cycle and is a crucial process in developing brains but it also takes place in adult brains where neurogenesis is required for the proper functioning of the mature neural network [23].

After the cell cycle withdrawal, newly generated neurons activate different programs of differentiation and migration [24]. Once the neurons are fully differentiated, they are considered post-mitotic cells and remain in a quiescent differentiated state (G0). They lose their capacity for cell cycle re-entry, which is probably promoted by changes in the expression of region-specific CDKIs $[25,26]$. However, the expression of cell cycle regulators persist after differentiation and are expressed in a manner that cannot be solely accounted for by differences in cell cycle rates [27], indicating that its role in neurogenesis is not only linked to cell cycle regulation. An increasing body of evidence has demonstrated that CDKIs have cell cycle-independent functions to coordinate cell cycle exit and neuronal differentiation, maturation and migration [28].

The majority of neuronal cells in the adult brain are fully differentiated and neurogenesis only persists in restricted brain areas; namely, the subventricular zone (SVZ) of the lateral ventricles and the subgranular zone (SGZ) of the hippocampal dentate gyrus (DG), the two main neurogenic niches [29].

The SVZ is the largest area in the adult brain where neurogenesis occurs; the resident neural stem cells (NSC) are primary progenitor cells that undergo numerous stages to finally originate mature neurons, astrocytes and oligodendrocytes [30]. The cells born in the adult SVZ (NSC, type B1 cells) express GFAP and can divide symmetrically and asymmetrically. Asymmetrical division commits to intermediate progenitors called type $\mathrm{C}$ cells, which after a mitotical division give rise to migratory neuroblasts (type A cells). The neuroblast, after one or two round divisions, exits the cycle, migrates towards the olfactory bulb and becomes newborn neuronal cells (post-mitotic immature neurons). A small group of these cells will survive and subsequently differentiate into granule cells [31]. A high expression of the CDK inhibitor p57 and p18-induced cell cycle arrest is required to maintain the production of undifferentiated NSC cells, inhibiting proliferation and differentiation [32,33].

The SVZ gives rise mostly to dopaminergic and $\gamma$-aminobutyric acidergic (GABAergic) interneurons that migrate from the rostral migratory stream and integrate into the olfactory bulb, playing an important role in the development of optimal olfactory circuitry where they participate in the processing of sensory inputs [34,35]. In physiological conditions, Type B1 cells also give rise to a few oligodendrocytes and astrocytes but in case of brain injury can produce more astrocytes that migrate to the damaged area [36].

In the SGZ, type 1 cells (radial glia-like precursors) divide asymmetrically, giving rise to transit amplifying cells (type 2 cells, GFAP-negative), which are highly proliferative. After several days of division, these generate type 3 cells that enter into a post-mitotic stage characterized by the expression of neuronal nuclei (NeuN) and calretinin (CR) $[37,38]$. Newly generated granule cells migrate radially into the granular cell layer where they develop dendrites and differentiate into glutamatergic granule cells, which are integrated into the neural circuitry of the hippocampus [39-41]. The degree of adult neurogenesis in the dentate gyrus correlates with the performance of animal models in hippocampusdependent learning tasks $[42,43]$, which suggests that neurogenesis is linked to memory and learning processes. Likewise, a decrease in neurogenesis in the DG during aging may contribute to age-dependent cognitive decline, tau hyperphosphorylation and a risk of Alzheimer's disease [44-47]. 
Under physiological conditions, neurogenesis in the hippocampus is a dynamic and well-controlled process but it can be increased or decreased in different conditions, such as by physical activity or by irradiation, respectively [48-50]. Different pathological conditions, including psychiatric diseases, strokes or neurodegenerative disorders can also modulate neurogenesis [51,52].

In the last decades, new neurogenesis areas have been described in the adult mammalian brain in the hypothalamus, substantia nigra, striatum and amygdala [53-56]. However, these studies are still incomplete and more research is needed to confirm that neurogenesis takes place in these areas [57]. There are still many open questions related to adult neurogenesis. Discrepancies and differences between studies, probably due to technical problems, together with the very low number of newly generated neurons incorporated into the neuronal circuit make neurogenesis one of the most discussed topics in neuroscience.

To summarize, neurogenesis involves, in cell cycle terms, re-entering and exiting the cell cycle. The SVZ and DG are the two main neurogenic niches. The modulation of cell cycle components is not only related to the number of cells (proliferation) but also to cell linage differentiation.

\subsection{Cell Cycle and $A D$}

Alzheimer's disease (AD) is a neurodegenerative disease and the most common cause of dementia in late life. Most of the people affected are over 65 years of age and the prevalence raises dramatically between 65 and 85 years [58]. Brain lesions start long before the onset of cognitive problems; this is named the preclinical phase of the disease. The disease progresses with the deposition of $\beta$-amyloid $(A \beta)$ in senile plaques and the formation of intracellular neurofibrillary tangles (NFTs) composed of the hyperphosphorylated tau protein. The hippocampus is one of the brain areas that earliest exhibits the damage and as the disease progresses, it spreads to other cortical areas (frontal and entorhinal cortex and another limbic areas), triggering a significant reduction in neuronal density in various regions $[59,60]$. When a massive loss of neurons takes place, the disease becomes symptomatic, starting with a slight cognitive decline of recently acquired information. It becomes worse with time, severely affecting cognitive dysfunction and other abnormal behaviors. In the late stage of the disease, the brain function continues to decline and the disease affects the autonomy of these patients [61]. The diagnosis of AD is based on different tests but a complete certain diagnosis can only be achieved by a post-mortem observation of the brain parenchyma and the presence of senile plaques and neurofibrillary tangles made up by the hyperphosphorylated tau protein (p-tau) [62].

Despite progress in the field, the precise pathogenic mechanisms of the neurodegenerative processes leading to AD remain elusive. In 1990, patients with Down syndrome showed AD-like dementia symptoms, starting the hypothesis that the aneuploidy (chromosome 21 trisomy) was causal to AD and a mutation in the genes involved in the cell cycle could lead to AD development [63]. More recent evidence, including -omics data from AD patients, has shown that an abnormal activation of the cell cycle components can contribute to neuronal death in AD [64-68]. Furthermore, these cycle event alterations are found in the early disease process of AD before significant pathological changes occur [69-72]. These data suggest that a group of neurons newly enter a defective cell cycle and most of them cannot progress to complete their cell division, thus undergoing apoptotic cell death [73]. Despite other studies reporting conflicting results [74,75], solid evidence supports the idea of increased aneuploidy in the neurons of AD patients. Interestingly, 13 out of the 37 genes that are frequently mutated in AD are functionally involved in the regulation of the cell cycle or mitosis (review in [76]).

p53 is a transcription factor that regulates the expression of the genes involved in critical cellular functions, such as cell cycle re-entry, DNA damage repair, developmental differentiation and senescence [77]. It has the ability to promote cell cycle arrest in several cell types and apoptosis in others. It is known as the "guardian of the genome" to limit the deleterious consequences of mutation [78]. During the development of the central nervous 
system (CNS), p53 is expressed in neuroblasts and is downregulated when migrating neurons reach their place [79]. In physiological conditions, p53 is maintained at low basal levels and its dysfunction has detrimental consequences, including cancer, metabolic disorders and neurodegenerative diseases. Elevated p53 immunoreactivity has been observed in sporadic and familial AD and in animal models [80,81]. p53 expression increases in parallel with an intracellular accumulation of $A \beta$ [82] and induces tau phosphorylation in HEK293a cells [81]. It has been demonstrated that p53 oligomerizes in AD brains and interacts with tau oligomers, triggering the loss of the nuclear p53 function and contributing to AD pathology [83].

Interestingly, regulators of the cell cycle-including CDKs, CDKIs and p53-also regulate the autophagic processes $[84,85]$, indicating that autophagy is intimately connected to the cell cycle [86]. Autophagy is also a basic physiologic process crucial to maintaining cellular homeostasis by clearing protein aggregates. AD, in common with other neurodegenerative diseases, is linked to the accumulation of misfolded proteins, suggesting that autophagy dysfunction probably contributes to AD pathogenesis [87-89].

Various studies have reported the overexpression of cell cycle protein regulators, such as CDKs, in the vicinity of NFTs and senile plaques in the post-mortem brains of AD patients $[68,90]$, indicating that the overexpression of the regulators of the cell cycle may be a characteristic feature of AD. Consistently, the administration of CDKIs (inhibitors of CDK1, 2, 4, 5, 7, 9) ameliorated AD symptoms in animal models [91-96], corroborating that the cell cycle and mitosis play an important role in AD development and could become important targets of drug research. In this sense, CDKIs have been suggested to be of potential relevance in the treatment of $\mathrm{AD}$ [93].

Altogether, the connection between neuronal loss and cell cycle re-entry in AD has been described. Although the underlying mechanism of cycle re-entry in AD is not completely understood, the role of $A \beta$ as a trigger of this aberrant cell cycle re-entry in post-mitotic neurons can be hypothesized, which in turn can initiate apoptotic neuronal death.

2. $\mathbf{p} 27^{\mathrm{Kip} 1}$

\section{1. $p 27^{\text {Kip } 1}$ and Its Role in the Cell Cycle Progression}

The cyclin-dependent kinase inhibitor p27 ${ }^{\mathrm{Kip} 1}$ (named p27) participates in many biological processes, such as cell proliferation, differentiation, migration and apoptosis [97]. p27 has been extensively studied for its role in cancer as a tumor suppressor [98]. It plays fundamental roles in all phases of the cell division cycle. Specifically, nuclear p27 inhibits cell cycle progression and makes the cell susceptible to quiescence, apoptosis and/or senescence. Extensive studies have been conducted in this regard. p27 is expressed in the quiescent stem cells of the adult hippocampus and is induced in immature neurons upon differentiation, suggesting that p27 can act as a controller of the cell cycle exit and differentiation, keeping adult hippocampal stem cells out of the cycle [99]. Hörster et al. [100] analyzed the role of p27 in the transition of precursor cells to post-mitotic maturation in adult hippocampal neurogenesis. In the DG, p27 shows a strong nuclear expression in early post-mitotic neurons (type 3 and a few type 2) and it has a lower or an absent expression in radial glia-like precursor cells (type 1) and type 2 cells with no expression in granule cells. Thus, the p27 nuclear function may have a transitory role in late proliferative and early post-mitotic phases of neurogenesis. Neurogenesis was abrogated in $\mathrm{p} 27^{-/-}$mice whereas the content of proliferating cells was promoted [100]. Concerning neurogenesis, p27 plays an important role in adult brain neurogenesis and the deletion of p27 impaired neurogenesis due to the increase of intermediate progenitor cells [101,102].

Mechanistically, p27 prevents the G1/S transition by repressing the CDK2-cyclin E and CDK4-cyclin D complexes [103]. It also participates in the control of the G2 and M phases $[103,104]$. A depletion of p27 protein in the late G1 phase promotes the transition to the S phase [105], allowing cell division progress. p27 protein levels are controlled through the regulation of translation and ubiquitination-dependent protein degradation. The levels of p27 decrease when the cells exit the quiescent state due to this ubiquitin-mediated 
degradation but the levels of p27 can also increase in response to anti-proliferative signals, such as serum starvation [106].

In summary, p27 is a key regulator of cell proliferation. When p27 binds to and inhibits cyclin-CDK, it arrests the cell cycle and opposes cell cycle progression.

\subsection{Extra Cell Cycle Regulatory Functions of 27}

To control the progression of the cell cycle in the nucleus, several cell cycle-related proteins, including p27, have an extra cell cycle regulatory function after exiting from the cell cycle [107]. These functions include regulating cytoskeletal organization, proliferation, differentiation and apoptosis. In most tumors, nuclear p27 regulates the cell cycle, which leads to the growth inhibition of cancer cells whereas in the cytoplasm, it is oncogenic. In cortical neurons treated with $A \beta 42$, the overexpression of $p 27$ induces apoptosis through the stabilization of the CDK5-cyclin D complex as this stabilization prevents the interaction of CDK5-p35 [108].

The activity of p27 is mainly dependent on post-translational modifications, such as phosphorylation and others (for example, ubiquitination and acetylation), on different residues and on their subcellular (nuclear vs. cytoplasmic) localization [104]. The phosphorylation of p27 determines its degradation by the ubiquitin system and the sequestration in the cytoplasm, precluding its nuclear function as a CDK inhibitor [109]. p27 is phosphorylated on many sites, including tyrosine $(\operatorname{Tyr}(\mathrm{Y}) 74,88,89)$, threonine $(\operatorname{Thr} 157,187,198)$ and Ser10 (Table 1).

As shown in Figure 2, when the cell enters the G1 phase, the phosphorylation of p27 on Ser10 by AKT (protein kinase B), CDK5 or KIS (kinase interacting stathmin) promotes the exportation of $\mathrm{p} 27$ from the nucleus to the cytoplasm by CRM1 (chromosome region maintenance 1), a carrier protein for nuclear export [110]. When p27 stays in the cytoplasm, Ser10 phosphorylation allows KPC (ubiquitylation promoting complex)-dependent degradation. Furthermore, CDK5 stabilizes p27 through Ser10 phosphorylation, increasing the p27 protein in the cytoplasm. Therefore, CDK5 is an unconventional cyclin-dependent kinase and is neuron-specific, able to phosphorylate p27 both at Ser10 in the N-terminal as well as at Thr187 in the C-terminal [5,111]. Other phosphorylation sites are at Thr157 and Thr198, which avoid nuclear import and result in the cytoplasmatic location of p27. This phosphorylation can be induced by AKT, AMPK, p90 ribosomal protein $\mathrm{S} 6$ kinases, serum glucocorticoid-inducible kinase (SGK) or PIM (proto-oncogene serine/threonine-protein kinase) [111-113].

Table 1. Phosphorylation sites of $\mathrm{p} 27^{\mathrm{Kip} 1}$ : its role in cellular localization and function.

\begin{tabular}{cccc}
\hline Subcellular Localization & Phosphorylate Site & Phosphorylated by & Function \\
\hline Nuclear & Thr187 & $\begin{array}{c}\text { CDK2-cyclin E; MERK/EK; } \\
\text { CDK5 }\end{array}$ & Degradation by Skp2 [109] \\
\hline Nuclear, cytoplasmatic & Ser10 & AKT; CDK5 & Nuclear export [110,111] \\
\hline Cytoplasmatic & Thr198 or/and Thr157 & $\begin{array}{c}\text { AKT; AMPK; GSK; } \\
\text { MERK-ERK }\end{array}$ & Blocked nuclear import [109] \\
\hline Cytoplasmatic & Thr198 and Ser10 & $\begin{array}{c}\text { AKT; AMPK; CDK5; } \\
\text { MERK-ERK }\end{array}$ & $\begin{array}{c}\text { Microtubes and actin } \\
\text { organization [114,115] }\end{array}$ \\
\hline Cytoplasmatic & $\begin{array}{c}\text { Independent of } \\
\text { phosphorylation }\end{array}$ & - & $\begin{array}{c}\text { Axonal transport via } \\
\text { stabilization ATA1 [116] }\end{array}$ \\
\hline Cytoplasmatic & $\begin{array}{c}\text { Independent of } \\
\text { phosphorylation }\end{array}$ & - & $\begin{array}{c}\text { Increment autophagy via } \\
\text { LAMTOR1 [117] }\end{array}$ \\
\hline
\end{tabular}




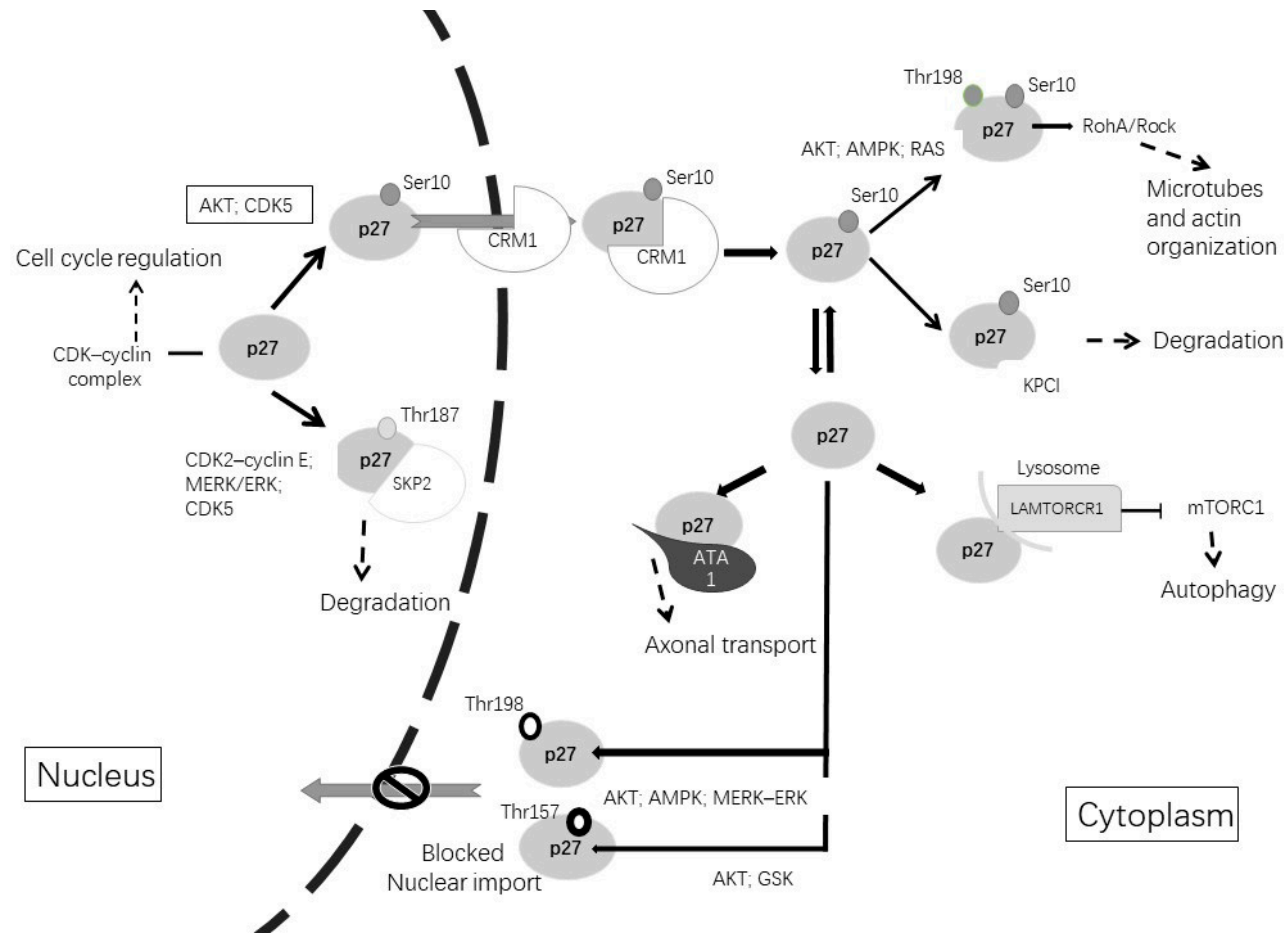

Figure 2. Post-translational modifications of $\mathrm{p} 27^{\mathrm{Kip} 1}$ lead to changes in its function and alter its subcellular localization. The phosphorylation of $\mathrm{p}^{27^{\mathrm{Kip}} 1}$ at Thr187 promotes its degradation in the nucleus. Phosphorylation of $\mathrm{p}^{27^{\mathrm{kip}} 1}$ at Ser10 promotes exportation to the cytoplasm by CRM1. Once in the cytoplasm, p27 ${ }^{\mathrm{Kip} 1}$ can be degraded or can undergo different phosphorylations. Phosphorylation at Thr157 or Thr198 avoids nuclear reimportation. Cytoplasmic functions include microtubules and actin organization, axonal transport or involvement in autophagy.

In the cytoplasm, p27 associates with microtubules and it is required for proper axonal transport, neuronal migration and dendritic spine formation [114-116]. The phosphorylation of p27 at Thr198 by RSK1 induces the interaction with RhoA and a subsequent reduction in RhoA-GTP binding, promoting cell migration and motility [118]. In cortical interneurons, p27 regulates nucleokinesis and promotes tangential migration and neurite branching by controlling the activity of myosin II through the Rho kinase pathway [119]. Studies in Drosophila and in rodents revealed that p27 regulates the axonal transport of vesicles and organelles through the stabilization of alpha-tubulin acetyltransferase 1 (ATAT1), which promotes the acetylation of microtubules. The neuronal depletion of p27 results in axonal transport defects that can be rescued by treatment with histone deacetylase inhibitors that increase the levels of tubulin acetylation [116].

All these alterations in the cytoskeleton and impaired axonal transport play an integral role in the pathogenesis of $\mathrm{AD}$. On the one hand, the cytoskeleton is crucial for dendritic spine formation, which is necessary for a correct synaptic activity. On the other hand, axonal transport is a process that uses microtubules to deliver diverse cargoes (including organelles, mitochondria and vesicles) along the axon, which is essential for nerve development, function and survival [120-122].

To summarize, p27 has several extra cell cycle regulatory functions in addition to controlling the cell cycle. These functions include regulating cytoskeletal organization, proliferation, differentiation and apoptosis. The subcellular localization and activity are dependent on post-translational modifications.

\section{3. $p 27$ and $A D$}

A few studies have analyzed a purported relationship between the alterations in p27 and AD. In an immunohistochemical study, it was found that the levels of cytoplasmic p27 
and phosphorylated p27 (Thr187) were increased in the hippocampal pyramidal neurons in AD compared with age-matched control subjects [123]. Interestingly, the increase in phosphorylated p27 (Thr187) overlapped with the tau-positive neurofibrillary pathology, including neurofibrillary tangles, dystrophic neurites and neuropil threads, indicating a possible direct implication of phosphorylated p27 in AD pathogenesis [123]. However, an increase in p27 was observed in both tangle-bearing as well as tangle-free neurons, suggesting that an increase in p27 was not directly related to the pathology in AD. It was suggested that phosphorylation at Thr187 could be associated with the activation of either the cyclin E/CDK2 or MAPK/ERK (mitogen-activated protein kinase) pathways.

In another study, it was reported that the half-life of the $\mathrm{p} 27$ protein in lymphoblasts from AD patients was markedly reduced compared with those in healthy patients [124]. In this study, an increased phosphorylation of $\mathrm{p} 27$ at Thr187 mediated by the $\mathrm{Ca}^{2+} / \mathrm{CaM}-$ dependent overactivation of PI3K/AKT was suggested to be responsible for an enhanced degradation of p27 in AD cells. The degradation of p27 favors the progression of the cell cycle and an enhanced cell proliferation [124]. It is of note that these cell cycle disturbances might be considered to be systemic manifestations that mirror the pathological changes that take place in the brain. For instance, the overactivation of the pro-survival PI3K/AKT signaling pathway in AD brain that takes place to protect neurons [125] can lower the levels of p27 and, in post-mitotic neurons, can eventually lead to neuronal death [126].

Regarding animal models, increased levels of the p27 protein were found in the cerebral cortex of APPswe/PS $\triangle \mathrm{E} 9$ mice compared with age-matched controls [127]. In this case, the levels of $\mathrm{p} 27$ were regulated through a post-transcriptional mechanism mediated by the downregulation of the microRNA 222 (miR-222). This particular non-coding small RNA bound to the $3^{\prime}$-UTR of p27, triggering its translational repression [127].

The role of $A \beta 42$ in the regulation of p27 levels and/or phosphorylation in AD that may lead to apoptosis has been speculated. In cortical post-mitotic mature neurons, p27 promoted neuronal apoptosis in the presence of $A \beta 42$ [108]. These authors suggested that $A \beta 42$ stabilized the CDK5-cyclin D1 complex with a subsequent decrease in CDK5, preventing its interaction with its neuron-specific activator p35. A depletion of p27 restored the CDK5-p35 interaction, inhibited the MAPK/ERK pathway and cyclin D1 expression and avoided the neuronal apoptosis mechanism. A $\beta 42$ and other neurotoxic agents promoted p35 proteolytic cleavage to $\mathrm{p} 25$. It has been shown that p25 accumulates in the brain of AD patients and induces the mislocalization and aberrant activation of CDK5 that can promote tau hyperphosphorylation, leading to neuronal cell death [68]. Interestingly, the inhibition of CDK5 is able to reduce cell death in A $\beta 42$-treated neurons.

A relation between autophagy and p27 ${ }^{\mathrm{Kip}}$ has also been reported $[117,128,129]$. Autophagy is a catabolic process directed to degrade and recycle damaged organelles and misfolded proteins. The most predominant form is macroautophagy, in which a double membrane structure (named autophagosomes) surrounds the damaged organelle or protein and is exposed to lysosomes for degradation [130]. The dysfunction of autophagy is suggested to lead to the accretion of noxious proteins, such as $A \beta 42$ or phosphorylated tau in the AD brain [131]. It has been suggested that p27 can drive apoptosis or autophagy following AMPK activation. AMPK phosphorylation of $\mathrm{p} 27$ on Thr198 promotes $\mathrm{p} 27$ protein stability and increases the levels of cytoplasmatic p27, resulting in greater autophagy and fewer apoptotic processes [98]. Other authors have proposed that the mechanism responsible for p27-controlled autophagy is regulated via mTOR (mammalian target of rapamycin) [117]. As reviewed [131], mTOR activation is an important fact in AD, which can lead to the impairment of autophagy. A fraction of p27 is recruited into the lysosomes where it binds to the LAMTOR1 subunit, avoiding the regulator-rag complex assembly, thus preventing mTORC1 activation [117].

In relationship with both $\mathrm{AD}$ alterations and autophagy, another important cellular pathway to consider is PI3K/ATK. Alterations in this pathway have been described in AD in correlation with diabetes mellitus type $2[132,133]$ and can affect p27 expression and phosphorylation (Figure 3). Altered insulin signaling increases phosphorylated PI3K 
and the activation of AKT, which leads to the phosphorylation of mTORC1, inhibiting autophagy. Therefore, AKT regulates the p27 nuclear export and sequestration of p27 in the cytoplasm [109]. Furthermore, mTORC1 activates SGK1, a protein kinase component of the PI3K-AKT pathway, which phosphorylates p27 at Thr157; therefore, it is retained in the cytoplasm [134].

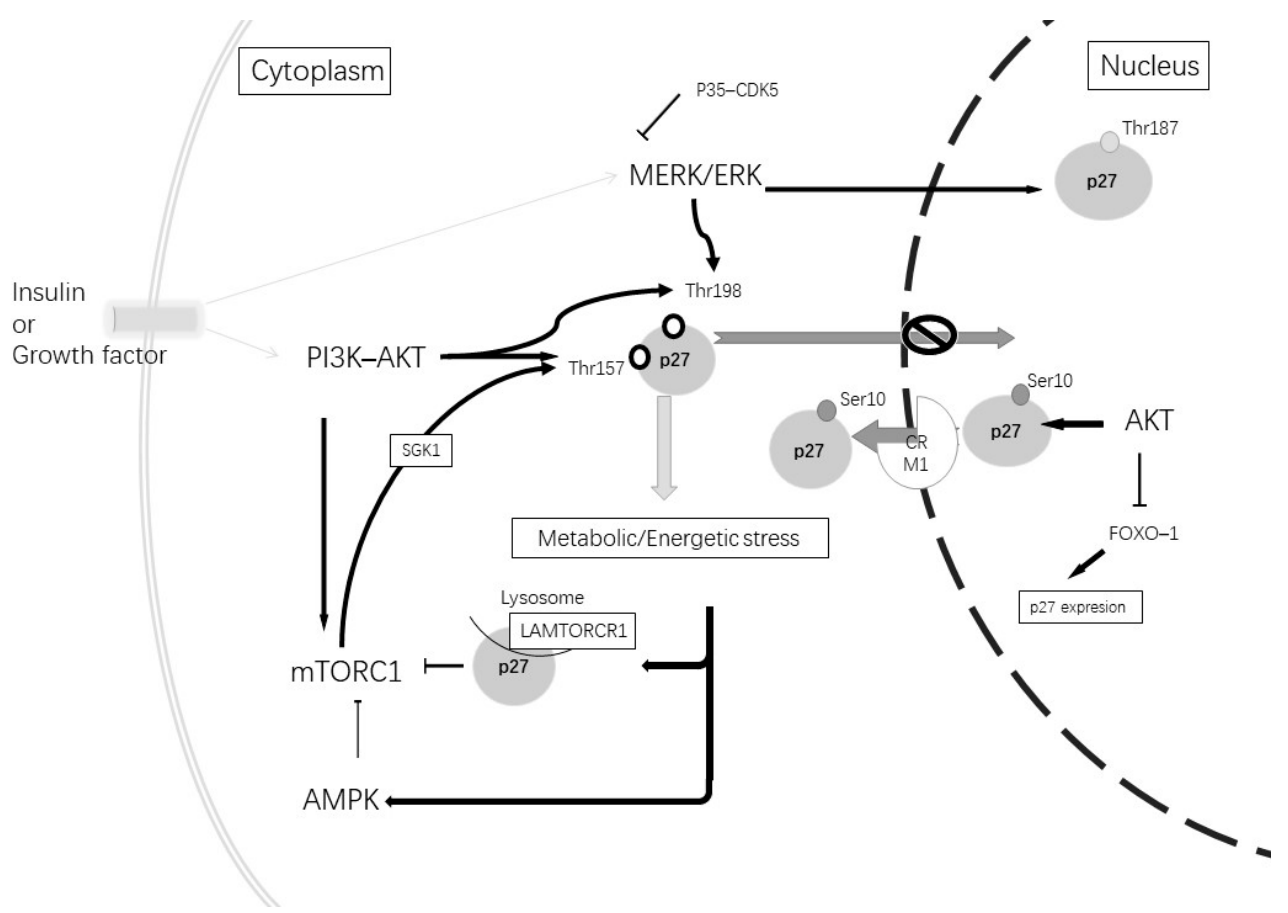

Figure 3. Insulin or growth factors can stimulate tyrosine kinase inducing the activation of the MERK-ERK and PI3K-AKT pathways. The activation of the MERK-ERK pathway stimulates p27Kip1 phosphorylation at Thr187, which induces its degradation. Its phosphorylation at Thr198 produces p27 ${ }^{\text {Kip } 1}$ cytoplasmic retention. The MERK-ERK pathway can be inhibited by p35 and the CDK5 complex. The activation of the PI3K-AKT pathway causes mTORC1 activation and causes phosphorylation at Thr157 through SGK1. Furthermore, AKT can phosphorylate at Thr198 and Thr157, which causes $\mathrm{p} 27^{\mathrm{Kip} 1}$ cytoplasmic retention. AKT at a nuclear level phosphorylates Ser10, promoting p2 ${ }^{\mathrm{kip} 1}$ nuclear export and can induce the inhibition of FoxO1 TFs and repress the gene expression of p27 ${ }^{\mathrm{Kip} 1}$. A metabolic or energetic stress condition induces mTORCR1 inhibition by the induction of p27 ${ }^{\text {Kip } 1}$ binding to LAMTORCR1 and AMPK pathway activation. In addition, AMPK phosphorylates p27 ${ }^{\text {Kip1 }}$ at Thr198.

In summary, the re-expression of cell cycle-related proteins in $\mathrm{AD}$ has been shown. Stimuli, such as A $\beta 42$, might lead to an abortive re-entry into the cell cycle and, ultimately, neuronal degeneration. The dysregulation of the cell cycle, therefore, might play a crucial role in the pathogenesis of AD, which may provide a novel mechanistic basis for therapeutic interventions.

\section{Concluding Remarks}

In conclusion, cell cycle activation plays a role in the pathophysiology of neurodegenerative diseases, including AD, and cell cycle re-entry is considered to be one of the key causes of neuronal death in the illness. Therefore, the cell cycle provides a potential target for treatments and therapies.

The cell cycle coordination needs a complex interplay between the levels of various cyclins and CDKs at different checkpoints. The involvement of aberrant cell cycle re-entry in the pathogenesis and progression of neurodegenerative diseases could be inhibited by the action of cyclin and CDK-specific inhibitors. However, CDKI inhibitors, such as p27 not 
only play a key role in cell cycle control but also post-transcriptional modifications, such as phosphorylation, contribute to extra cell cycle functions or even increase the degradation. In the nucleus, $\mathrm{p} 27^{\mathrm{Kip} 1}$ inhibits the cell cycle progression and makes the cell susceptible to quiescence and apoptosis. However, in the cytoplasm, p2 ${ }^{\mathrm{Kip} 1}$ has been found to promote cellular resilience through autophagy and anti-apoptotic mechanisms [98]. Altogether, all these nuclear and extra-nuclear functions allow a correct neurogenesis, maintaining a quiescent state in the post-mitotic neurons. As already detected in $\mathrm{AD}$, the attempt of neurons to re-enter the mitosis in response to external stimuli (such as $A \beta 42$, p-tau or insulin resistance) leads to an abortive re-entry into the cell cycle and, ultimately, neuronal degeneration. In this sense, the increase in both p27 and phosphorylated p27 (Thr187) in the AD neurons may reflect an effort of the susceptible neurons to stop the cell cycle. Further studies will shed light on the role of p27 at the cytoplasmic level to better understand the involvement of $\mathrm{p} 27$ in the mechanisms related to $\mathrm{AD}$ progression.

One of the pending affairs in $\mathrm{AD}$ is to find early biomarkers for sporadic $\mathrm{AD}$, which could identify patients before substantial pathology develops. Nowadays, by the time the disease is diagnosed, the pathology has spread, causing irreversible damage and functional disability. The fact that it is possible to detect changes in the p27 protein levels in lymphocytes from AD patients, which could mirror changes thought to occur in the brain prior to neurodegeneration, could offer new venues for diagnostic tools. Furthermore, the identification of therapeutic targets directed to normalize the cellular content of p27, thus reducing the activity of CDKs and cell cycle activation, could also open new venues for $\mathrm{AD}$ treatment. In this sense, CDKIs, by preventing CDK inactivation, might constitute a promising venture for the treatment of AD. However, although several CDKIs have been reported in the literature to treat other diseases, such as cancer, few studies have been conducted to investigate their effects against neurodegeneration. Not only that but also various side effects may arise due to the non-specificity of CDKIs, which may affect several CDKs, leading to controversial opinions towards its use [93]. Therefore, achieving a higher selectivity might be considered to be one of the most important aspects in the field of CDKI development.

Funding: The authors acknowledge support by Navarra Government-Centros Tecnológicos 00111383-2019-000005 (PC056-057) and CIBER Physiopathology of Obesity and Nutrition (CIBERobn CB12/03/30002), Carlos III Health Institute as well as from Ministry of Science and Innovation (PID2019-104921RB-I00/MCI/AEI/10.13039/501100011033), and the Foundation for Applied Medical Research (CIMA) and the University of Navarra (Pamplona, Spain) for financial support.

Institutional Review Board Statement: Not applicable.

Informed Consent Statement: Not applicable.

Conflicts of Interest: The authors declare no conflict of interest.

\section{References}

1. Fisher, R.P. The CDK Network: Linking Cycles of Cell Division and Gene Expression. Genes Cancer 2013, 3, 731-738. [CrossRef] [PubMed]

2. Matthews, H.K.; Bertoli, C.; de Bruin, R.A.M. Cell cycle control in cancer. Nat. Rev. Mol. Cell Biol. 2021, 23, 74-88. [CrossRef] [PubMed]

3. Skotheim, J.M.; Di Talia, S.; Siggia, E.D.; Cross, F.R. Positive feedback of G1 cyclins ensures coherent cell cycle entry. Nature 2008, 454, 291-296. [CrossRef] [PubMed]

4. Hochegger, H.; Takeda, S.; Hunt, T. Cyclin-dependent kinases and cell-cycle transitions: Does one fit all? Nat. Rev. Mol. Cell Biol. 2008, 9, 910-916. [CrossRef]

5. Kawauchi, T. Cdk5 regulates multiple cellular events in neural development, function and disease. Dev. Growth Differ. 2014, 56, 335-348. [CrossRef]

6. Łukasik, P.; Baranowska-bosiacka, I.; Kulczycka, K.; Gutowska, I. Inhibitors of cyclin-dependent kinases: Types and their mechanism of action. Int. J. Mol. Sci. 2021, 22, 2806. [CrossRef]

7. Zou, T.; Lin, Z. The Involvement of Ubiquitination Machinery in Cell Cycle Regulation and Cancer Progression. Int. J. Mol. Sci. 2021, 22, 5754. [CrossRef] 
8. Frade, J.M.; Ovejero-Benito, M.C. Neuronal cell cycle: The neuron itself and its circumstances. Cell Cycle 2015, 14, 712-720. [CrossRef]

9. Leal-Esteban, L.C.; Fajas, L. Cell cycle regulators in cancer cell metabolism. Biochim. Biophys. Acta Mol. Basis Dis. 2020, 1866. [CrossRef]

10. Liu, N.; Lucibello, F.C.; Engeland, K.; Müller, R. A new model of cell cycle-regulated transcription: Repression of the cyclin A promoter by CDF-1 and anti-repression by E2F. Oncogene 1998, 16, 2957-2963. [CrossRef]

11. Ohtsubo, M.; Theodoras, A.M.; Schumacher, J.; Roberts, J.M.; Pagano, M. Human cyclin E, a nuclear protein essential for the G1-to-S phase transition. Mol. Cell. Biol. 1995, 15, 2612-2624. [CrossRef] [PubMed]

12. Deshpande, A.; Sicinski, P.; Hinds, P.W. Cyclins and cdks in development and cancer: A perspective. Oncogene 2005, 24, 2909-2915. [CrossRef] [PubMed]

13. Łukasik, P.; Załuski, M.; Gutowska, I. Cyclin-dependent kinases (Cdk) and their role in diseases development-Review. Int. J. Mol. Sci. 2021, 22, 2935. [CrossRef] [PubMed]

14. Denicourt, C.; Dowdy, S.F. Cip/Kip proteins: More than just CDKs inhibitors. Genes Dev. 2004, 18, 851-855. [CrossRef] [PubMed]

15. Graña, X.; Reddy, E. Cell cycle control in mammalian cells: Role of cyclins, cyclin dependent kinases (CDKs), growth suppressor genes and cyclin-dependent kinase inhibitors (CKIs). Oncogene 1995, 11, 211-219. [PubMed]

16. Coqueret, O. New roles for p21 and p27 cell-cycle inhibitors: A function for each cell compartment? Trends Cell Biol. 2003, 13, 65-70. [CrossRef]

17. Di Micco, R.; Krizhanovsky, V.; Baker, D.; d'Adda di Fagagna, F. Cellular senescence in ageing: From mechanisms to therapeutic opportunities. Nat. Rev. Mol. Cell Biol. 2021, 22, 75-95. [CrossRef]

18. Rovillain, E.; Mansfield, L.; Lord, C.J.; Ashworth, A.; Jat, P.S. An RNA interference screen for identifying downstream effectors of the p53 and pRB tumour suppressor pathways involved in senescence. BMC Genom. 2011, 12, 355. [CrossRef]

19. Kumari, R.; Jat, P. Mechanisms of Cellular Senescence: Cell Cycle Arrest and Senescence Associated Secretory Phenotype. Front. Cell Dev. Biol. 2021, 9, 645593. [CrossRef]

20. Childs, B.G.; Durik, M.; Baker, D.J.; Van Deursen, J.M. Cellular senescence in aging and age-related disease: From mechanisms to therapy. Nat. Med. 2015, 21, 1424-1435. [CrossRef]

21. Childs, B.G.; Baker, D.J.; Wijshake, T.; Conover, C.A.; Campisi, J.; Van Deursen, J.M. Senescent intimal foam cells are deleterious at all stages of atherosclerosis. Science 2016, 354, 472-477. [CrossRef] [PubMed]

22. Bussian, T.J.; Aziz, A.; Meyer, C.F.; Swenson, B.L.; van Deursen, J.M.; Baker, D.J. Clearance of senescent glial cells prevents tau-dependent pathology and cognitive decline. Nature 2018, 562, 578-582. [CrossRef] [PubMed]

23. Zhao, C.; Deng, W.; Gage, F.H. Mechanisms and Functional Implications of Adult Neurogenesis. Cell 2008, 132, 645-660. [CrossRef] [PubMed]

24. Nguyen, L.; Besso, A.; Roberts, J.; Guillemot, F. Coupling Cell Cycle Exit, Neuronal Differentiation and Migration in Cortical Neurogenesis. Cell Cycle 2006, 5, 2314-2318. [CrossRef]

25. Legrier, M.; Ducray, A.; Propper, A.; Kastner, A. Region-specific expression of cell cycle inhibitors in the adult brain. Neuroreport 2001, 12, 3127-3131. [CrossRef]

26. Watanabe, G.; Pena, P.; Shambaugh, G.E.; Haines, G.K.; Pestell, R.G. Regulation of cyclin dependent kinase inhibitor proteins during neonatal cerebella development. Dev. Brain Res. 1998, 108, 77-87. [CrossRef]

27. Vernon, A.E.; Philpott, A. A single cdk inhibitor, p27Xic1, functions beyond cell cycle regulation to promote muscle differentiation in Xenopus. Development 2003, 130, 71-83. [CrossRef]

28. Tury, A.; Mairet-Coello, G.; Dicicco-Bloom, E. The multiple roles of the cyclin-dependent kinase inhibitory protein p57(KIP2) in cerebral cortical neurogenesis. Dev. Neurobiol. 2012, 72, 821-842. [CrossRef] [PubMed]

29. Ming, G.L.; Song, H. Adult neurogenesis in the mammalian brain: Significant answers and significant questions. Neuron 2011, 70, 687-702. [CrossRef]

30. Kempermann, G.; Jessberger, S.; Steiner, B.; Kronenberg, G. Milestones of neuronal development in the adult hippocampus Trends Neurosci. 2004, 27, 447-452. [CrossRef]

31. Lois, C.; Alvarez-Buylla, A. Long-Distance Neuronal Migration in the Adult Mammalian Brain. Science 1994, $264,1145-1148$. [CrossRef] [PubMed]

32. Harada, Y.; Yamada, M.; Imayoshi, I.; Kageyama, R.; Suzuki, Y.; Kuniya, T.; Furutachi, S.; Kawaguchi, D.; Gotoh, Y. Cell cycle arrest determines adult neural stem cell ontogeny by an embryonic Notch-nonoscillatory Hey1 module. Nat. Commun. 2021, 12, 6562. [CrossRef] [PubMed]

33. Furutachi, S.; Miya, H.; Watanabe, T.; Kawai, H.; Yamasaki, N.; Harada, Y.; Imayoshi, I.; Nelson, M.; Nakayama, K.I.; Hirabayashi, Y.; et al. Slowly dividing neural progenitors are an embryonic origin of adult neural stem cells. Nat. Neurosci. 2015, 18, 657-665. [CrossRef] [PubMed]

34. Lazarini, F.; Gabellec, M.M.; Moigneu, C.; De Chaumont, F.; Olivo-Marin, J.C.; Lledo, P.M. Adult neurogenesis restores dopaminergic neuronal loss in the olfactory bulb. J. Neurosci. 2014, 34, 14430-14442. [CrossRef] [PubMed]

35. Lledo, P.M.; Valley, M. Adult Olfactory Bulb Neurogenesis. Cold Spring Harb. Perspect. Biol. 2016, 8. [CrossRef] [PubMed]

36. Benner, E.J.; Luciano, D.; Jo, R.; Abdi, K.; Paez-Gonzalez, P.; Sheng, H.; Warner, D.; Liu, C.; Eroglu, C.; Kuo, C.T. Post-injury protective astrogenesis from SVZ niche is controlled by Notch modulator Thbs4. Nature 2013, 497, 369. [CrossRef] 
37. Brandt, M.D.; Jessberger, S.; Steiner, B.; Kronenberg, G.; Reuter, K.; Bick-Sander, A.; Von Der Behrens, W.; Kempermann, G. Transient calretinin expression defines early postmitotic step of neuronal differentiation in adult hippocampal neurogenesis of mice. Mol. Cell. Neurosci. 2003, 24, 603-613. [CrossRef]

38. Kempermann, G.; Kuhn, H.G.; Gage, F.H. Genetic influence on neurogenesis in the dentate gyrus of adult mice. Proc. Natl. Acad. Sci. USA 1997, 94, 10409-10414. [CrossRef]

39. Ambrogini, P.; Lattanzi, D.; Ciuffoli, S.; Agostini, D.; Bertini, L.; Stocchi, V.; Santi, S.; Cuppini, R. Morpho-functional characterization of neuronal cells at different stages of maturation in granule cell layer of adult rat dentate gyrus. Brain Res. 2004, 1017, 21-31. [CrossRef]

40. Van Praag, H.; Schinder, A.F.; Christie, B.R.; Toni, N.; Palmer, T.D.; Gage, F.H. Functional neurogenesis in the adult hippocampus. Nature 2002, 415, 1030-1034. [CrossRef]

41. Wang, S.; Scott, B.; Wojtowicz, J. Heterogenous properties of dentate granule neurons in the adult rat. J. Neurobiol. 2000, 42, 248-257. [CrossRef]

42. Drapeau, E.; Montaron, M.-F.; Aguerre, S.; Abrous, D.N. Learning-Induced Survival of New Neurons Depends on the Cognitive Status of Aged Rats. J. Neurosci. 2007, 27, 6037. [CrossRef] [PubMed]

43. Gould, E.; Beylin, A.; Tanapat, P.; Reeves, A.; Shors, T.J. Learning enhances adult neurogenesis in the hippocampal formation. Nat. Neurosci. 1999, 2, 260-265. [CrossRef] [PubMed]

44. Bizon, J.L.; Gallagher, M. Production of new cells in the rat dentate gyrus over the lifespan: Relation to cognitive decline. Eur. J. Neurosci. 2003, 18, 215-219. [CrossRef]

45. Bizon, J.L.; Lee, H.J.; Gallagher, M. Neurogenesis in a rat model of age-related cognitive decline. Aging Cell 2004, 3, 227-234. [CrossRef]

46. Drapeau, E.; Abrous, D.N. Stem Cell Review Series: Role of neurogenesis in age-related memory disorders. Aging Cell 2008, 7, 569-589. [CrossRef]

47. Hollands, C.; Tobin, M.K.; Hsu, M.; Musaraca, K.; Yu, T.S.; Mishra, R.; Kernie, S.G.; Lazarov, O. Depletion of adult neurogenesis exacerbates cognitive deficits in Alzheimer's disease by compromising hippocampal inhibition. Mol. Neurodegener. 2017, 12, 64. [CrossRef]

48. Ben Abdallah, N.M.B.; Slomianka, L.; Vyssotski, A.L.; Lipp, H.P. Early age-related changes in adult hippocampal neurogenesis in C57 mice. Neurobiol. Aging 2010, 31, 151-161. [CrossRef]

49. Fabel, K.; Kempermann, G. Physical activity and the regulation of neurogenesis in the adult and aging brain. Neuromol. Med. 2008, 10, 59-66. [CrossRef]

50. Naylor, A.S.; Bull, C.; Nilsson, M.K.L.; Zhu, C.; Björk-Eriksson, T.; Eriksson, P.S.; Blomgren, K.; Kuhn, H.G. From the Cover: Voluntary running rescues adult hippocampal neurogenesis after irradiation of the young mouse brain. Proc. Natl. Acad. Sci. USA 2008, 105, 14632. [CrossRef]

51. Ruan, L.; Lau, B.W.M.; Wang, J.; Huang, L.; ZhuGe, Q.; Wang, B.; Jin, K.; So, K.F. Neurogenesis in neurological and psychiatric diseases and brain injury: From bench to bedside. Prog. Neurobiol. 2014, 115, 116-137. [CrossRef] [PubMed]

52. Arias-Carrion, O.; Freundlieb, N.; Oertel, W.; Hoglinger, G. Adult Neurogenesis and Parkinsons Disease. CNS Neurol. Disord.Drug Targets 2008, 6, 326-335. [CrossRef] [PubMed]

53. Pérez-Martín, M.; Cifuentes, M.; Grondona, J.M.; López-Ávalos, M.D.; Gómez-Pinedo, U.; García-Verdugo, J.M.; FernándezLlebrez, P. IGF-I stimulates neurogenesis in the hypothalamus of adult rats. Eur. J. Neurosci. 2010, 31, 1533-1548. [CrossRef] [PubMed]

54. Zhao, M.; Momma, S.; Delfani, K.; Carlén, M.; Cassidy, R.M.; Johansson, C.B.; Brismar, H.; Shupliakov, O.; Frisén, J.; Janson, A.M Evidence for neurogenesis in the adult mammalian substantia nigra. Proc. Natl. Acad. Sci. USA 2003, 100, 7925-7930. [CrossRef]

55. Bernier, P.J.; Bédard, A.; Vinet, J.; Lévesque, M.; Parent, A. Newly generated neurons in the amygdala and adjoining cortex of adult primates. Proc. Natl. Acad. Sci. USA 2002, 99, 11464-11469. [CrossRef]

56. Dayer, A.G.; Cleaver, K.M.; Abouantoun, T.; Cameron, H.A. New GABAergic interneurons in the adult neocortex and striatum are generated from different precursors. J. Cell Biol. 2005, 168, 415-427. [CrossRef]

57. Leal-galicia, P.; Chávez-hernández, M.E.; Mata, F.; Mata-luévanos, J.; Rodríguez-serrano, L.M.; Tapia-de-jesús, A.; Buenrostrojáuregui, M.H. Adult Neurogenesis: A Story Ranging from Controversial New Neurogenic Areas and Human Adult Neurogenesis to Molecular Regulation. Int. J. Mol. Sci. 2021, 22, 11489. [CrossRef]

58. 2021 Alzheimer's disease facts and figures. Alzheimer's Dement. 2021, 17, 327-406. [CrossRef]

59. Duyckaerts, C.; Delatour, B.; Potier, M.-C. Classification and basic pathology of Alzheimer disease. Acta Neuropathol. 2009, 118, 5-36. [CrossRef]

60. Small, S.A.; Perera, G.M.; DeLaPaz, R.; Mayeux, R.; Stern, Y. Differential Regional Dysfunction of the Hippocampal Formation among Elderly with Memory Decline and Alzheimer's Disease. Ann. Neurol. 1999, 45, 466-472. [CrossRef]

61. Nelson, P.T.; Alafuzoff, I.; Bigio, E.H.; Bouras, C.; Braak, H.; Cairns, N.J.; Castellani, R.J.; Crain, B.J.; Davies, P.; Del Tredici, K.; et al. Correlation of Alzheimer Disease Neuropathologic Changes with Cognitive Status: A Review of the Literature. J. Neuropathol. Exp. Neurol. 2012, 71, 362. [CrossRef] [PubMed]

62. DeTure, M.A.; Dickson, D.W. The neuropathological diagnosis of Alzheimer's disease. Mol. Neurodegener. 2019, 14, 32. [CrossRef] [PubMed] 
63. Potter, H. Review and hypothesis: Alzheimer disease and Down syndrome-Chromosome 21 nondisjunction may underlie both disorders. Am. J. Hum. Genet. 1991, 48, 1192. [PubMed]

64. Yang, S.-S.; Zhang, R.; Wang, G.; Zhang, Y.-F. The development prospection of HDAC inhibitors as a potential therapeutic direction in Alzheimer's disease. Transl. Neurodegener. 2017, 6, 19. [CrossRef]

65. Smyth, G.K. Linear models and empirical bayes methods for assessing differential expression in microarray experiments. Stat. Appl. Genet. Mol. Biol. 2004, 3, 3. [CrossRef]

66. Irizarry, R.A.; Bolstad, B.M.; Collin, F.; Cope, L.M.; Hobbs, B.; Speed, T.P. Summaries of Affymetrix GeneChip probe level data Nucleic Acids Res. 2003, 31, e15. [CrossRef]

67. Hooper, C.; Coley, N.; De Souto Barreto, P.; Payoux, P.; Salabert, A.S.; Andrieu, S.; Weiner, M.; Vellas, B. Cortical $\beta$-Amyloid in Older Adults Is Associated with Multidomain Interventions with and without Omega 3 Polyunsaturated Fatty Acid Supplementation. J. Prev. Alzheimer's Dis. 2020, 7, 128-134. [CrossRef]

68. Arendt, T.; Holzer, M.; Gärtner, U. Neuronal expression of cycline dependent kinase inhibitors of the INK4 family in Alzheimer's disease. J Neural Transm 1998, 105, 949-960. [CrossRef]

69. Arendt, T.; Brückner, M.K.; Morawski, M.; Jäger, C.; Gertz, H.-J. Early neurone loss in Alzheimer's disease: Cortical or subcortical? Acta Neuropathol. Commun. 2015, 3, 10. [CrossRef]

70. Iourov, I.Y.; Vorsanova, S.G.; Liehr, T.; Yurov, Y.B. Aneuploidy in the normal, Alzheimer's disease and ataxia-telangiectasia brain: Differential expression and pathological meaning. Neurobiol. Dis. 2009, 34, 212-220. [CrossRef]

71. Nagy, Z.; Esiri, M.M.; Cato, A.-M.; Smith, A.D. Cell cycle markers in the hippocampus in Alzheimer's disease. Acta Neuropathol. 1997, 94, 6-15. [CrossRef]

72. Nagy, Z.; Esiri, M.M.; Smith, A.D. Expression of cell division markers in the hippocampus in Alzheimer's disease and other neurodegenerative conditions. Acta Neuropathol. 1997, 93, 294-300. [CrossRef] [PubMed]

73. Van Leeuwen, L.A.G.; Hoozemans, J.J.M. Physiological and pathophysiological functions of cell cycle proteins in post-mitotic neurons: Implications for Alzheimer's disease. Acta Neuropathol. 2015, 129, 511. [CrossRef] [PubMed]

74. Van den Bos, H.; Spierings, D.C.J.; Taudt, A.S.; Bakker, B.; Porubský, D.; Falconer, E.; Novoa, C.; Halsema, N.; Kazemier, H.G.; Hoekstra-Wakker, K.; et al. Single-cell whole genome sequencing reveals no evidence for common aneuploidy in normal and Alzheimer's disease neurons. Genome Biol. 2016, 17, 116. [CrossRef] [PubMed]

75. Westra, J.W.; Barral, S.; Chun, J. A Reevaluation of Tetraploidy in the Alzheimer's Disease Brain. Neurodegener. Dis. 2010, 6, 221. [CrossRef] [PubMed]

76. Rao, C.V.; Asch, A.S.; Carr, D.J.J.; Yamada, H.Y. “Amyloid-beta accumulation cycle" as a prevention and/or therapy target for Alzheimer's disease. Aging Cell 2020, 19, e13109. [CrossRef] [PubMed]

77. Kastenhuber, E.R.; Lowe, S.W. Putting p53 in Context. Cell 2017, 170, 1062-1078. [CrossRef] [PubMed]

78. Lane, D.P. Cancer. p53, guardian of the genome. Nature 1992, 358, 15-16. [CrossRef] [PubMed]

79. Ferreira, A.; Kosik, K.S. Accelerated neuronal differentiation induced by p53 suppression. J. Cell Sci. 1996, 109 (Pt 6), 1509-1516. [CrossRef]

80. Farmer, K.M.; Ghag, G.; Puangmalai, N.; Montalbano, M.; Bhatt, N.; Kayed, R. P53 aggregation, interactions with tau, and impaired DNA damage response in Alzheimer's disease. Acta Neuropathol. Commun. 2020, 8, 132. [CrossRef]

81. Hooper, C.; Meimaridou, E.; Tavassoli, M.; Melino, G.; Lovestone, S.; Killick, R. p53 is upregulated in Alzheimer's disease and induces tau phosphorylation in HEK293a cells. Neurosci. Lett. 2007, 418, 34-37. [CrossRef] [PubMed]

82. Ohyagi, Y.; Asahara, H.; Chui, D.-H.; Tsuruta, Y.; Sakae, N.; Miyoshi, K.; Yamada, T.; Kikuchi, H.; Taniwaki, T.; Murai, H.; et al Intracellular Abeta42 activates p53 promoter: A pathway to neurodegeneration in Alzheimer's disease. FASEB J. 2005, 19, 1-29. [CrossRef] [PubMed]

83. Jazvinšćak Jembrek, M.; Slade, N.; Hof, P.R.; Šimić, G. The interactions of p53 with tau and Aß as potential therapeutic targets for Alzheimer's disease. Prog. Neurobiol. 2018, 168, 104-127. [CrossRef] [PubMed]

84. White, E. Autophagy and p53. Cold Spring Harb. Perspect. Med. 2016, 6, a026120. [CrossRef]

85. Capparelli, C.; Chiavarina, B.; Whitaker-Menezes, D.; Pestell, T.G.; Pestell, R.G.; Hulit, J.; Andò, S.; Howell, A.; MartinezOutschoorn, U.E.; Sotgia, F.; et al. CDK inhibitors (p16/p19/p21) induce senescence and autophagy in cancer-associated fibroblasts, "fueling" tumor growth via paracrine interactions, without an increase in neo-angiogenesis. Cell Cycle 2012, 11, 3599-3610. [CrossRef]

86. Mathiassen, S.G.; De Zio, D.; Cecconi, F. Autophagy and the Cell Cycle: A Complex Landscape. Front. Oncol. 2017, 7, 51. [CrossRef]

87. Di Meco, A.; Curtis, M.E.; Lauretti, E.; Praticò, D. Autophagy Dysfunction in Alzheimer's Disease: Mechanistic Insights and New Therapeutic Opportunities. Biol. Psychiatry 2020, 87, 797-807. [CrossRef]

88. Ghavami, S.; Shojaei, S.; Yeganeh, B.; Ande, S.R.; Jangamreddy, J.R.; Mehrpour, M.; Christoffersson, J.; Chaabane, W.; Moghadam, A.R.; Kashani, H.H.; et al. Autophagy and apoptosis dysfunction in neurodegenerative disorders. Prog. Neurobiol. 2014, 112, 24-49. [CrossRef]

89. Yang, C.; Cai, C.Z.; Song, J.X.; Tan, J.Q.; Durairajan, S.S.K.; Iyaswamy, A.; Wu, M.Y.; Chen, L.L.; Yue, Z.; Li, M.; et al. NRBF2 is involved in the autophagic degradation process of APP-CTFs in Alzheimer disease models. Autophagy 2017, 13, 2028-2040. [CrossRef] 
90. Zhu, X.; Rottkamp, C.A.; Raina, A.K.; Brewer, G.J.; Ghanbari, H.A.; Boux, H.; Smith, M.A. Neuronal CDK7 in hippocampus is related to aging and Alzheimer disease. Neurobiol. Aging 2000, 21, 807-813. [CrossRef]

91. Allnutt, A.B.; Waters, A.K.; Kesari, S.; Yenugonda, V.M. Physiological and Pathological Roles of Cdk5: Potential Directions for Therapeutic Targeting in Neurodegenerative Disease. ACS Chem. Neurosci. 2020, 11, 1218-1230. [CrossRef] [PubMed]

92. Leggio, G.M.; Catania, M.V.; Puzzo, D.; Spatuzza, M.; Pellitteri, R.; Gulisano, W.; Torrisi, S.A.; Giurdanella, G.; Piazza, C.; Impellizzeri, A.R.; et al. The antineoplastic drug flavopiridol reverses memory impairment induced by Amyloid-\$1-42 oligomers in mice. Pharmacol. Res. 2016, 106, 10-20. [CrossRef] [PubMed]

93. Malhotra, N.; Gupta, R.; Kumar, P. Pharmacological relevance of CDK inhibitors in Alzheimer's disease. Neurochem. Int. 2021, 148, 105115. [CrossRef] [PubMed]

94. Senderowicz, A. Flavopiridol: The first cyclin-dependent kinase inhibitor in human clinical trials. Investig. New Drugs 1999, 17, 313-320. [CrossRef] [PubMed]

95. Wilkaniec, A.; Gąssowska-Dobrowolska, M.; Strawski, M.; Adamczyk, A.; Czapski, G.A. Inhibition of cyclin-dependent kinase 5 affects early neuroinflammatory signalling in murine model of amyloid beta toxicity. J. Neuroinflamm. 2018, 15, 1. [CrossRef]

96. Zhang, X.; Hernandez, I.; Rei, D.; Mair, W.; Laha, J.K.; Cornwell, M.E.; Cuny, G.D.; Tsai, L.-H.; Steen, J.A.J.; Kosik, K.S. Diaminothiazoles Modify Tau Phosphorylation and Improve the Tauopathy in Mouse Models. J. Biol. Chem. 2013, $288,22042$. [CrossRef]

97. Polyak, K. The p27Kip1 tumor suppressor gene: Still a suspect or proven guilty? Cancer Cell 2006, 10, 352-354. [CrossRef] [PubMed]

98. McKay, L.K.; White, J.P. The AMPK/p27Kip1 Pathway as a Novel Target to Promote Autophagy and Resilience in Aged Cells. Cells 2021, 10, 1430. [CrossRef]

99. Andreu, Z.; Khan, M.A.; González-Gómez, P.; Negueruela, S.; Hortigüela, R.; Emeterio, J.S.; Ferrón, S.R.; Martínez, G.; Vidal, A.; Fariñas, I.; et al. The Cyclin-Dependent Kinase Inhibitor p27kip1 Regulates Radial Stem Cell Quiescence and Neurogenesis in the Adult Hippocampus. Stem Cells 2015, 33, 219-229. [CrossRef]

100. Hörster, H.; Garthe, A.; Walker, T.L.; Ichwan, M.; Steiner, B.; Khan, M.A.; Lie, D.C.; Nicola, Z.; Ramirez-Rodriguez, G.; Kempermann, G. p27kip1 Is Required for Functionally Relevant Adult Hippocampal Neurogenesis in Mice. Stem Cells 2017, 35, 787-799. [CrossRef]

101. Doetsch, F.; Verdugo, J.M.-G.; Caille, I.; Alvarez-Buylla, A.; Chao, M.V.; Casaccia-Bonnefil, P. Lack of the Cell-Cycle Inhibitor p27Kip1 Results in Selective Increase of Transit-Amplifying Cells for Adult Neurogenesis. J. Neurosci. 2002, 22, 2255. [CrossRef] [PubMed]

102. Gil-Perotin, S.; Haines, J.D.; Kaur, J.; Marin-Husstege, M.; Spinetta, M.J.; Kim, K.-H.; Duran-Moreno, M.; Schallert, T.; Zindy, F.; Roussel, M.F.; et al. Roles of p53 and p27Kip1 in the regulation of neurogenesis in the murine adult subventricular zone. Eur. J. Neurosci. 2011, 34, 1040-1052. [CrossRef] [PubMed]

103. James, M.K.; Ray, A.; Leznova, D.; Blain, S.W. Differential Modification of p27Kip1 Controls Its Cyclin D-cdk4 Inhibitory Activity. Mol. Cell. Biol. 2008, 28, 498. [CrossRef] [PubMed]

104. Bencivenga, D.; Stampone, E.; Roberti, D.; Della Ragione, F.; Borriello, A. p27 Kip1, an Intrinsically Unstructured Protein with Scaffold Properties. Cells 2021, 10, 2254. [CrossRef]

105. Tsytlonok, M.; Hemmen, K.; Hamilton, G.; Kolimi, N.; Felekyan, S.; Seidel, C.A.M.; Tompa, P.; Sanabria, H. Specific Conformational Dynamics and Expansion Underpin a Multi-Step Mechanism for Specific Binding of p27 with Cdk2/Cyclin A. J. Mol. Biol. 2020, 432, 2998-3017. [CrossRef]

106. Cheng, M.; Sexl, V.; Sherr, C.J.; Roussel, M.F. Assembly of cyclin D-dependent kinase and titration of p27Kip1 regulated by mitogen-activated protein kinase kinase (MEK1). Proc. Natl. Acad. Sci. USA 1998, 95, 1091. [CrossRef]

107. Akagawa, R.; Nabeshima, Y.I.; Kawauchi, T. Alternative Functions of Cell Cycle-Related and DNA Repair Proteins in Post-mitotic Neurons. Front. Cell Dev. Biol. 2021, 9, 753175. [CrossRef]

108. Jaiswal, S.; Sharma, P. Role and regulation of p27 in neuronal apoptosis. J. Neurochem. 2017, 140, 576-588. [CrossRef]

109. Abbastabar, M.; Kheyrollah, M.; Azizian, K.; Bagherlou, N.; Tehrani, S.S.; Maniati, M.; Karimian, A. Multiple functions of p27 in cell cycle, apoptosis, epigenetic modification and transcriptional regulation for the control of cell growth: A double-edged sword protein. DNA Repair 2018, 69, 63-72. [CrossRef]

110. Serres, M.P.; Zlotek-Zlotkiewicz, E.; Concha, C.; Gurian-West, M.; Daburon, V.; Roberts, J.M.; Besson, A. Cytoplasmic p27 is oncogenic and cooperates with Ras both in vivo and in vitro. Oncogene 2011, 30, 2846-2858. [CrossRef]

111. Zheng, Y.-L.; Li, B.-S.; Rudrabhatla, P.; Shukla, V.; Amin, N.D.; Maric, D.; Kesavapany, S.; Kanungo, J.; Pareek, T.K.; Takahashi, S.; et al. Phosphorylation of p27Kip1 at Thr187 by Cyclin-dependent Kinase 5 Modulates Neural Stem Cell Differentiation. Mol. Biol. Cell 2010, 21, 3601. [CrossRef] [PubMed]

112. Cassimere, E.K.; Mauvais, C.; Denicourt, C. p27Kip1 Is Required to Mediate a G1 Cell Cycle Arrest Downstream of ATM following Genotoxic Stress. PLoS ONE 2016, 11, e0162806. [CrossRef] [PubMed]

113. Cuadrado, M.; Gutierrez-Martinez, P.; Swat, A.; Nebreda, A.R.; Fernandez-Capetillo, O. p27kip1 stabilization is essential for the maintenance of cell cycle arrest in response to DNA damage. Cancer Res. 2009, 69, 8726. [CrossRef] [PubMed]

114. Godin, J.D.; Thomas, N.; Laguesse, S.; Malinouskaya, L.; Close, P.; Malaise, O.; Purnelle, A.; Raineteau, O.; Campbell, K.; Fero, M.; et al. p27Kip1 Is a Microtubule-Associated Protein that Promotes Microtubule Polymerization during Neuron Migration. Dev. Cell 2012, 23, 729-744. [CrossRef] 
115. Kawauchi, T.; Chihama, K.; Nabeshima, Y.; Hoshino, M. Cdk5 phosphorylates and stabilizes p27kip1 contributing to actin organization and cortical neuronal migration. Nat. Cell Biol. 2005, 8, 17-26. [CrossRef]

116. Morelli, G.; Even, A.; Gladwyn-Ng, I.; Le Bail, R.; Shilian, M.; Godin, J.D.; Peyre, E.; Hassan, B.A.; Besson, A.; Rigo, J.M.; et al. p27Kip1 Modulates Axonal Transport by Regulating $\alpha$-Tubulin Acetyltransferase 1 Stability. Cell Rep. 2018, 23, $2429-2442$. [CrossRef]

117. Nowosad, A.; Jeannot, P.; Callot, C.; Creff, J.; Perchey, R.T.; Joffre, C.; Codogno, P.; Manenti, S.; Besson, A. p27 controls Ragulator and mTOR activity in amino acid-deprived cells to regulate the autophagy-lysosomal pathway and coordinate cell cycle and cell growth. Nat. Cell Biol. 2020, 22, 1076-1090. [CrossRef] [PubMed]

118. Larrea, M.D.; Hong, F.; Wander, S.A.; da Silva, T.G.; Helfman, D.; Lannigan, D.; Smith, J.A.; Slingerland, J.M. RSK1 drives p27Kip1 phosphorylation at T198 to promote RhoA inhibition and increase cell motility. Proc. Natl. Acad. Sci. USA 2009, 106, 9268. [CrossRef] [PubMed]

119. Besson, A.; Gurian-West, M.; Schmidt, A.; Hall, A.; Roberts, J.M. p27Kip1 modulates cell migration through the regulation of RhoA activation. Genes Dev. 2004, 18, 862-876. [CrossRef] [PubMed]

120. Pelucchi, S.; Stringhi, R.; Marcello, E. Dendritic Spines in Alzheimer's Disease: How the Actin Cytoskeleton Contributes to Synaptic Failure. Int. J. Mol. Sci. 2020, 21, 908. [CrossRef] [PubMed]

121. Sleigh, J.N.; Rossor, A.M.; Fellows, A.D.; Tosolini, A.P.; Schiavo, G. Axonal transport and neurological disease. Nat. Rev. Neurol. 2019, 15, 691-703. [CrossRef] [PubMed]

122. Wang, Z.-X.; Tan, L.; Yu, J.-T. Axonal Transport Defects in Alzheimer's Disease. Mol. Neurobiol. 2014, 51, 1309-1321. [CrossRef]

123. Ogawa, O.; Lee, H.; Zhu, X.; Raina, A.; Harris, P.L.R.; Castellani, R.J.; Perry, G.; Smith, M.A. Increased p27, an essential component of cell cycle control, in Alzheimer's disease. Aging Cell 2003, 2, 105-110. [CrossRef] [PubMed]

124. Muñoz, Ú.; Bartolomé, F.; Bermejo, F.; Martín-Requero, Á. Enhanced proteasome-dependent degradation of the CDK inhibitor p27kip1 in immortalized lymphocytes from Alzheimer's dementia patients. Neurobiol. Aging 2008, 29, 1474-1484. [CrossRef] [PubMed]

125. Griffin, R.J.; Moloney, A.; Kelliher, M.; Johnston, J.A.; Ravid, R.; Dockery, P.; O'Connor, R.; O’Neill, C. Activation of Akt/PKB, increased phosphorylation of Akt substrates and loss and altered distribution of Akt and PTEN are features of Alzheimer's disease pathology. J. Neurochem. 2005, 93, 105-117. [CrossRef] [PubMed]

126. Marino, S.; Krimpenfort, P.; Leung, C.; van der Korput, H.A.G.M.; Trapman, J.; Camenisch, I.; Berns, A.; Brandner, S. PTEN is essential for cell migration but not for fate determination and tumourigenesis in the cerebellum. Development 2002, 129, 3513-3522. [CrossRef] [PubMed]

127. Wang, X.; Xu, Y.; Zhu, H.; Ma, C.; Dai, X.; Qin, C. Downregulated microRNA-222 is correlated with increased p27Kip1 expression in a double transgenic mouse model of Alzheimer's disease. Mol. Med. Rep. 2015, 12, 7687-7692. [CrossRef]

128. Liang, J.; Shao, S.H.; Xu, Z.-X.; Hennessy, B.; Ding, Z.; Larrea, M.; Kondo, S.; Dumont, D.J.; Gutterman, J.U.; Walker, C.L.; et al. The energy sensing LKB1-AMPK pathway regulates p27kip1 phosphorylation mediating the decision to enter autophagy or apoptosis. Nat. Cell Biol. 2007, 9, 218-224. [CrossRef]

129. White, J.P.; Billin, A.N.; Campbell, M.E.; Russell, A.J.; Huffman, K.M.; Kraus, W.E. The AMPK/p27Kip1 Axis Regulates Autophagy/Apoptosis Decisions in Aged Skeletal Muscle Stem Cells. Stem Cell Rep. 2018, 11, 425. [CrossRef]

130. Settembre, C.; Fraldi, A.; Medina, D.L.; Ballabio, A. Signals for the lysosome: A control center for cellular clearance and energy metabolism. Nat. Rev. Mol. Cell Biol. 2013, 14, 283. [CrossRef]

131. Uddin, M.S.; Stachowiak, A.; Al Mamun, A.; Tzvetkov, N.T.; Takeda, S.; Atanasov, A.G.; Bergantin, L.B.; Abdel-Daim, M.M.; Stankiewicz, A.M. Autophagy and Alzheimer's Disease: From Molecular Mechanisms to Therapeutic Implications. Front. Aging Neurosci. 2018, 10, 4. [CrossRef] [PubMed]

132. Gabbouj, S.; Ryhänen, S.; Marttinen, M.; Wittrahm, R.; Takalo, M.; Kemppainen, S.; Martiskainen, H.; Tanila, H.; Haapasalo, A.; Hiltunen, M.; et al. Altered Insulin Signaling in Alzheimer's Disease Brain-Special Emphasis on PI3K-Akt Pathway. Front. Neurosci. 2019, 13, 629. [CrossRef] [PubMed]

133. Xu, F.; Na, L.; Li, Y.; Chen, L. Roles of the PI3K/AKT/mTOR signalling pathways in neurodegenerative diseases and tumours. Cell Biosci. 2020, 10, 54. [CrossRef] [PubMed]

134. Hong, F.; Larrea, M.D.; Doughty, C.; Kwiatkowski, D.J.; Squillace, R.; Slingerland, J.M. mTOR-Raptor Binds and Activates SGK1 to Regulate p27 Phosphorylation. Mol. Cell 2008, 30, 701-711. [CrossRef] [PubMed] 